\title{
THE EFFECTIVENESS OF TEACHERS' CORRECTIVE FEEDBACK IN ENHANCING STUDENTS' ABILITY TO RECOUNT TEXT WRITING
}

\author{
IRRA WAHIDIYATI \\ Fakultas Tarbiyah dan Ilmu Kependidikan IAIN Purwokerto \\ irrazkayra@iainpurwokerto.ac.id
}

First Received: 08-11-2019; Accepted: 05-03-2020

\begin{abstract}
Most junior high school students get some difficulties in recount text writing. The purpose of this research is to explain the kind of corrective feedback that is more effective for high achievers', for low achievers, and for mixed groups of high and low achievers in enhancing their ability in recount text writing and explain the interaction between corrective feedback, students' prior achievement, and ability in recount text writing. The samples are eighth-graders of SMP Agus Salim. The experiment group receives direct corrective feedback while the control group receives indirect corrective feedback. And from both groups, the researcher divides again into two groups of high and low achievers. Finally, direct feedback is more effective for mixed groups of high and low achievers. The sum of means score of the experimental group is 63.75 while the total means score of the control group is 63.50. The mean score of the high achievers that received direct corrective feedback is 62.00 , while the low achievers were 65.5. From the control group, the high achiever group mean is 66.00 while the low achiever group means is 61.00 . In short, direct corrective feedback is better used for low achievers.
\end{abstract}

Keywords: effectiveness, direct corrective feedback, indirect corrective feedback, writing, recount text.

\section{INTRODUCTION}

This study investigated the students' ability in writing recount text because the ability to write well is not a naturally acquired skill. It is usually learned or culturally transmitted as a set of practices in formal instructional settings or other environments.

The object of this study was the eighth graders of SMP Agus Salim. They had some difficulties in completing one of the assignments from the teacher. It was recount text writing. Most of them made some grammatical errors. For example, some of them generalized the rule in changing verb one to verb two. If the teachers asked them to write recount text based on their own experience, they would write it without paying attention that they should write it using verb two. They did not pay attention to the characteristics of recount text either, for example in the generic structure and lexicogrammatical features of recount text. 
Teachers sometimes ask the students to write a recount text based on their experiences but when the teachers collect the products of students' writing, the accuracy is still problematic. The students make a significant number of errors, both in linguistic items and grammatical elements of interlanguage writing. Dulay, et al (1982) stated making errors is an important part of learning. Teachers consequently cannot neglect and leave it alone without further attention. Thus, the followings are the objectives of the study:

1. To explain which corrective feedback that is more effective for high achievers' in enhancing their ability to recount text writing,

2. To explain which corrective feedback is more effective for a mixed group of high and low achievers in enhancing their ability to recount text writing,

3. To explain the interaction between teachers' corrective feedback and students' prior achievement in enhancing their ability to recount text writing.

\section{Feedback in Learning Theory}

Feedback is an important part of an instructional design model. Reigeluth (2011) affirms that feedback is a method of instruction that could help cognitive learning. Reigeluth, furthermore, cites an example of an instructional design theory called "Theory One" which was described by Perkins (1992). Those instructions should include informative feedback as well as other method such as clear information, thoughtful practice, and strong motivation.

\section{Feedback in the Teaching of ESL/EFL Writing}

Feedback on student writing can create an effective learning, as noted by Cardelle and Corno (1981), if the students receive more feedback of their performance; they understand better what they need to do to correct their mistakes. Feedback could also develop students' thinking or behavior toward their work or assignment and focus their attention on the purpose of writing. Carless (2006) confirms that students who receive feedback during the writing process have a clearer sense of how well they are writing and what they need to do to improve. Furthermore, feedback can improve students' attention to the subject they are writing. 


\section{Teacher's Corrective Feedback}

Corrective feedback is a type of feedback with the purpose to correct any errors which are committed by students. Corrective feedback which informs students of the correct response could assist the error correction (Dempsey, et al: 1993). Corrective feedback could take different forms of teacher response to students' texts that contain errors. Ellis, Loewen, and Erlam (2006) categorize responses from teachers to students' error into three strategies: (a) teacher feedback that indicates that an error has been committed, (b) teacher feedback that provides the correct form of the target language, and (c) teacher feedback that provides a type of metalinguistic information about the nature of the error

\section{Indirect feedback}

Indirect feedback is an approach of providing feedback typically used by teachers or facilitators to assist students errors by marking an error without providing the right form of the answer (Ferris: 2003). Through indirect feedback, students are challenged to reflect the clues given by the teacher or facilitator, who acts as a 'reflective agent' (Pollard: 1990) providing meaningful and appropriate guidance to students' cognitive structuring skills arising from students' previous experience.

\section{Direct feedback}

Another feedback strategy commonly used by teachers is direct feedback. Direct feedback is a strategy of giving feedback to students to assist them to correct their errors by giving the correct linguistic form (Ferris: 2003) or the linguistic structure of the target language. In some cases, direct feedback is more practical than indirect feedback. Because the students will know the correction of their mistakes, it was tested by Chandler (2003) direct corrective feedback gave result in the largest accuracy gains, not only in revisions but also in the next writing

\section{Teaching writing}

Teaching writing on EFL is to get things done and to make and maintain social relationships. In reality, the teacher could teach the students such as letters, notes, instructions, reports, etc. 


\section{The Effectiveness of Teachers' Corrective Feedback in Enhancing Students' Ability to Recount Text Writing}

Teaching writing is a way of conveying messages or keeps a record of what is in our mind into written form.

Adamson (2006) states that in a recent research analysis, teaching writing in ELT classroom is considered as a mean to consolidate language. Students often write from somebody else's opinion. It is "writing as language learning". In this stage, students are given a topic for constructing their writing. Moreover, in the ELT classroom, especially in traditional pedagogy, the teacher gives or selects the topics, a set of requirements, and a time limit. The students end the task within the deadline and submit the product. The students' work is evaluated based on the accuracy of the final product.

\section{Errors}

Brown (1980) stated that an error is a noticeable deviation from the adult grammar of native speaker, reflecting the interlanguage competence of the learners. These errors occur because of many things. Based on Corder (1982), error can be defined as a result of a lack of knowledge.

\section{Error correction}

Error correction is always helpful for teachers and students. Based on James (1998) summarized three senses of error correction, they are: giving information to the learners that there is an error, and leaving them to correct it and repair it, giving treatment or information that leads to the revision and correction of the specific examples of error without aiming to prevent the same error later, and giving information to the learners that allows them to revise or reject the wrong rule they were operating with when they produced the error token.

\section{Recount text}

In the teaching-learning process, recount text is taught in the eighth and ninth grade of senior high school. Based on Anderson (1997) a recount is a piece of text that retells past events, usually in the order in which they happened. The purpose of a recount text is to give the audience a description of what occurred in the past. To be able to produce a piece of writing, we should be able to write a connected series of words and sentences grammatically and logically linked, so the purpose in our mind will suit to intended readers. 


\section{Paragraph writing}

Before making a paragraph, we should consider three important points that we must remember. First, a topic sentence is a complete sentence that contains at least one subject and one verb. Second, it contains both a topic and a controlling idea. At last, the topic sentence is the most general statement because it gives only the main idea (Oshima: 2006).

\section{Prior achievement}

Based on Dahar (2009) prior achievement or the prior ability is an important indicator of the use of school resource inputs and the predictor of academic achievement. The prior achievement or the prior ability is the important indicator of the use of school resource inputs and the predictor of academic achievement. High achievement is the students' score that is satisfying, while the low achievement is the students' score that is not satisfying.

Table 1 Analytic scale for writing tasks (Brown:2004)

\begin{tabular}{|c|c|c|c|c|c|}
\hline & $\begin{array}{c}20-18 \\
\text { Excellent to } \\
\text { Good }\end{array}$ & $\begin{array}{c}17-15 \\
\text { Good to } \\
\text { Adequate }\end{array}$ & $\begin{array}{c}14-12 \\
\text { Adequate to } \\
\text { Fair }\end{array}$ & $\begin{array}{c}11-6 \\
\text { Unacceptable }\end{array}$ & $\begin{array}{c}5-1 \\
\text { Not college } \\
\text { level work }\end{array}$ \\
\hline Organization & $\begin{array}{l}\text { Appropriate } \\
\text { title, effective } \\
\text { introductory } \\
\text { paragraph, topic } \\
\text { is stated, leads } \\
\text { to body, } \\
\text { transitional } \\
\text { expression used, } \\
\text { arrangement of } \\
\text { material shows } \\
\text { plan, supporting } \\
\text { evidence given } \\
\text { for } \\
\text { generalizations, } \\
\text { conclusion } \\
\text { logical and } \\
\text { complete }\end{array}$ & $\begin{array}{l}\text { Adequate title, } \\
\text { introduction and } \\
\text { conclusion, } \\
\text { body of essay is } \\
\text { acceptable, but } \\
\text { some evidence } \\
\text { may be lacking, } \\
\text { some ideas } \\
\text { aren't fully } \\
\text { developed, } \\
\text { sequence is } \\
\text { logical but } \\
\text { transitional } \\
\text { expressions may } \\
\text { be absent or } \\
\text { misused }\end{array}$ & $\begin{array}{l}\text { Mediocre or } \\
\text { scant } \\
\text { introduction or } \\
\text { conclusion, } \\
\text { problems with } \\
\text { the order of } \\
\text { ideas in body, } \\
\text { the } \\
\text { generalizations } \\
\text { may not be fully } \\
\text { supported by } \\
\text { the evidence } \\
\text { given, problems } \\
\text { of organization } \\
\text { interfere }\end{array}$ & $\begin{array}{l}\text { Shaky or } \\
\text { minimally } \\
\text { recognizable } \\
\text { introduction, } \\
\text { organization can } \\
\text { barely seen, } \\
\text { severe problems } \\
\text { with ordering of } \\
\text { ideas, lack of } \\
\text { supporting } \\
\text { evidence, } \\
\text { conclusion } \\
\text { weak or } \\
\text { illogical, } \\
\text { inadequate } \\
\text { effort at } \\
\text { organization }\end{array}$ & $\begin{array}{l}\text { Absence of } \\
\text { introduction or } \\
\text { conclusion, no } \\
\text { apparent } \\
\text { organization of } \\
\text { body, severe } \\
\text { lack of } \\
\text { supporting } \\
\text { evidence, writer } \\
\text { has not made } \\
\text { any effort to } \\
\text { organize the } \\
\text { composition }\end{array}$ \\
\hline $\begin{array}{l}\text { Logical } \\
\text { development }\end{array}$ & $\begin{array}{l}\text { Essay addresses } \\
\text { the assigned } \\
\text { topic, the ideas } \\
\text { are concrete and } \\
\text { thoroughly } \\
\text { developed, no } \\
\text { extraneous } \\
\text { material, essay } \\
\text { reflects thought }\end{array}$ & $\begin{array}{l}\text { Essay addresses } \\
\text { the issues but } \\
\text { misses some } \\
\text { points, ideas } \\
\text { could be more } \\
\text { fully developed, } \\
\text { some } \\
\text { extraneous } \\
\text { material is } \\
\text { present }\end{array}$ & $\begin{array}{l}\text { Development of } \\
\text { ideas not } \\
\text { complete or } \\
\text { essay is } \\
\text { somewhat off } \\
\text { the topic, } \\
\text { paragraphs } \\
\text { aren't divided } \\
\text { exactly right }\end{array}$ & $\begin{array}{l}\text { Ideas } \\
\text { incomplete, } \\
\text { essay does not } \\
\text { reflect careful } \\
\text { thinking or was } \\
\text { hurriedly } \\
\text { written, } \\
\text { inadequate } \\
\text { effort in area of } \\
\text { content }\end{array}$ & $\begin{array}{l}\text { Essay is } \\
\text { completely } \\
\text { inadequate and } \\
\text { does not reflect } \\
\text { college level } \\
\text { work, no } \\
\text { apparent effort } \\
\text { to consider the } \\
\text { topic carefully }\end{array}$ \\
\hline
\end{tabular}




\begin{tabular}{|c|c|c|c|c|c|}
\hline Grammar & $\begin{array}{l}\text { Native like } \\
\text { fluency in } \\
\text { English } \\
\text { grammar, } \\
\text { correct use of } \\
\text { relative clauses, } \\
\text { prepositions, } \\
\text { modals, articles, } \\
\text { verb forms, and } \\
\text { tense } \\
\text { sequencing, no } \\
\text { fragments or } \\
\text { run on } \\
\text { sentences }\end{array}$ & $\begin{array}{l}\text { Advanced } \\
\text { proficiency in } \\
\text { English } \\
\text { grammar, some } \\
\text { grammar } \\
\text { problems don't } \\
\text { influence } \\
\text { communication, } \\
\text { although the } \\
\text { reader is aware } \\
\text { of them, no } \\
\text { fragments or } \\
\text { run on } \\
\text { sentences }\end{array}$ & $\begin{array}{l}\text { Ideas are getting } \\
\text { through to the } \\
\text { reader, but } \\
\text { grammar } \\
\text { problems are } \\
\text { apparent and } \\
\text { have a negative } \\
\text { effect on } \\
\text { communication, } \\
\text { run on } \\
\text { sentences or } \\
\text { fragments } \\
\text { present }\end{array}$ & $\begin{array}{l}\text { Numerous } \\
\text { serious } \\
\text { problems } \\
\text { interfere with } \\
\text { communication } \\
\text { of the writer's } \\
\text { ideas, grammar } \\
\text { review of some } \\
\text { areas clearly } \\
\text { needed, difficult } \\
\text { to read } \\
\text { sentences }\end{array}$ & $\begin{array}{l}\text { Severe grammar } \\
\text { problems } \\
\text { interfere greatly } \\
\text { with the } \\
\text { message, reader } \\
\text { can't understand } \\
\text { what the writer } \\
\text { was trying to } \\
\text { say, } \\
\text { unintelligible } \\
\text { sentence } \\
\text { structure }\end{array}$ \\
\hline $\begin{array}{l}\text { Punctuation, } \\
\text { spelling, and } \\
\text { mechanics }\end{array}$ & $\begin{array}{l}\text { Correct use of } \\
\text { English writing } \\
\text { conventions, } \\
\text { left and right } \\
\text { margins, all } \\
\text { needed capitals, } \\
\text { paragraphs } \\
\text { indented, } \\
\text { punctuation, } \\
\text { and spellings, } \\
\text { very neat }\end{array}$ & $\begin{array}{l}\text { Some problems } \\
\text { with writing } \\
\text { conventions or } \\
\text { punctuations, } \\
\text { occasional } \\
\text { spelling errors, } \\
\text { left margin } \\
\text { correct, paper is } \\
\text { neat and legible. }\end{array}$ & $\begin{array}{l}\text { Uses general } \\
\text { writing } \\
\text { conventions but } \\
\text { has errors, } \\
\text { spelling } \\
\text { problems } \\
\text { distract reader, } \\
\text { punctuation } \\
\text { errors interfere } \\
\text { with ideas }\end{array}$ & $\begin{array}{l}\text { Serious } \\
\text { problems with } \\
\text { format of paper, } \\
\text { parts of essay } \\
\text { not legible, } \\
\text { errors in } \\
\text { sentence } \\
\text { punctuation, } \\
\text { unacceptable to } \\
\text { educated } \\
\text { readers }\end{array}$ & $\begin{array}{l}\text { Complete } \\
\text { disregard for } \\
\text { English writing } \\
\text { conventions, } \\
\text { paper legible, } \\
\text { obvious capitals } \\
\text { missing, no } \\
\text { margins, severe } \\
\text { spelling } \\
\text { problems }\end{array}$ \\
\hline $\begin{array}{l}\text { Style and } \\
\text { quality of } \\
\text { expression }\end{array}$ & $\begin{array}{l}\text { Precise } \\
\text { vocabulary } \\
\text { usage, use of } \\
\text { parallel } \\
\text { structures. } \\
\text { Concise, } \\
\text { register good }\end{array}$ & $\begin{array}{l}\text { Attempts } \\
\text { variety, good } \\
\text { vocabulary, not } \\
\text { wordy, register } \\
\text { OK, style fairly } \\
\text { concise }\end{array}$ & $\begin{array}{l}\text { Some } \\
\text { vocabulary } \\
\text { misused, lacks } \\
\text { awareness of } \\
\text { register, may be } \\
\text { too wordy }\end{array}$ & $\begin{array}{l}\text { Poor expression } \\
\text { of ideas, } \\
\text { problems in } \\
\text { vocabulary, } \\
\text { lacks variety of } \\
\text { structure }\end{array}$ & $\begin{array}{l}\text { Inappropriate } \\
\text { use of } \\
\text { vocabulary, no } \\
\text { concept of } \\
\text { register or } \\
\text { sentence variety }\end{array}$ \\
\hline
\end{tabular}

\section{METHOD}

This research method consists of some parts, they are:

\section{Design of the Study}

This was an experimental study design that uses factorial design as it uses more than one independent variable. It involved two groups namely an experimental and control group. It was a pretest-posttest control group design. The experimental group was given a treatment called direct corrective feedback, while the control group got a treatment of indirect corrective feedback. After giving the treatments to the experimental and control groups, then it was time to assess their final writing. 


\section{Population and Sample}

The population of this research was grade VIII of SMP Agus Salim Semarang which consists of 148 students. The sample of this research was 40 students. The researcher had divided them into two groups. 20 students were for the experimental group, and 20 students were for the control group.

\section{Research Procedure}

This research process had been done through the following steps:

1. The researcher had provided pre-test (first draft) for both the experimental and control groups,

2. Treatments had been given by giving direct and indirect corrective feedback to students recount text writing,

3. Post-test (second draft) for both the experimental and control group. It had been done to get the data about the result of treatments in the experimental and control groups.

\section{FINDINGS AND DISCUSSION}

The present study was designed to determine the effectiveness of direct and indirect corrective feedback in enhancing students' ability in recount text writing. Recent investigations had pointed out that corrective feedback can have a positive effect on students' ability in writing. By corrective feedback, students could know their mistakes in writing so they would know the correction or made the correction by themselves.

The result of a similar study by Purnawarman suggested that by providing corrective feedback, students could get the benefit, for example, gained grammatical accuracy in subsequently revised drafts. Based on Srichanyachon N, giving effective feedback to the students could improve their writing and give finally the students were able to talk in the class to express their ideas and to discuss any challenging analytical issues into two categories, they are high achievers and low achievers.

In giving direct feedback, the teacher gave a cross or circle on the students' writing that contains mistakes or errors. The example of direct feedback was to give circle on the word 'go' in the sentence 'finally we went home' and then the teacher gave the correction and 


\section{The Effectiveness of Teachers' Corrective Feedback in Enhancing}

Students' Ability to Recount Text Writing

wrote 'went' near the circle because the students wrote recount text so they should use verb two. It proved that the teacher gave direct corrective feedback on students' recount text writing. The other example was when the student wrote 'I was so tired but my very happy'. The teacher gave a cross on the word 'my' and she gave the right correction, for example, wrote the word 'I was' near to the cross given. Thus, the students knew that they should use 'I was' in that sentence because the text was recount text.

In giving the indirect corrective feedback, the teacher just gave a cross or circle on students' worksheet, without giving the right words or the right correction. So, the students had to find the right correction by themselves.

The mean score of the high achievers that received direct corrective feedback was 62.00, while the low achievers were 65.5. From the control group, the high achiever group mean was 66.00 while the low achiever group means was 61.00. From the data, we could see that the use of direct feedback is more effective for low achiever group. And indirect feedback is more effective for high achiever group.

The mean of the experimental group is better than the control group. It means the students' ability to recount text writing in the experimental group (using direct corrective feedback) is better than the control group (using indirect corrective feedback). And from the output of Descriptive Statistics, it could be seen that the standard deviation of each and total variables. The total mean of the experimental group was 63.75 with a standard deviation of 9.716. While the total mean of the control group was 63.50 with the standard deviation of 9.473. So, the use of direct feedback is more effective for mixed high and low achievers.

From the output of Estimated Marginal Means of writing, it is shown that the significant number for variable group asterisk prior achievement was $0.170>0.05$. It means there was not an interaction between feedback and students' prior achievement to the students' ability in recount text writing.

\section{CONCLUSION}

From the result of the analysis, it can be concluded that: The use of direct corrective feedback in teaching writing is more effective for a mixed group of students (high and low achievers in one class). Because the means score of the experimental group who got direct feedback was higher than the means score of the control group who got indirect feedback. 
Then the use of direct corrective feedback is more effective for the students who have low prior achievement in English subjects because the low achievers' group of the experimental class got the better mean score than the high achievers in the control group. In addition, the use of indirect corrective feedback is more effective for the students who have high prior achievement in English subject because the high achievers who got direct corrective feedback have lower mean score than the means score of high achievers who got indirect corrective feedback. Based on the result of two ways ANOVA, there is not an interaction between corrective feedback given by the teacher, prior achievement, and students' ability in recount text writing.

The results of this study can be used to inform ESL/EFL teachers and researchers that are interested in applying various types of written corrective feedback strategies, including direct corrective feedback and indirect corrective feedback.

This study suggests that teachers' corrective feedback can be applied in any students' different prior achievement, for example, direct corrective feedback is better for low achievers and indirect corrective feedback is better for high achievers. So the teachers could adjust the appropriate corrective feedback that should be used in correcting their students' writing.

\section{REFERENCES}

Anderson, Kathy and Mark Anderson. (1997). Text Types in English. Sydney: Macmillan Education Australia.

Brown, H.D. (2006). Principles of Language Learning and Teaching. New Jersey: Prentice Hall Inc.

. (2004). Language Assessment: Principles and Classroom Practises. New York: Pearson Education, Inc.

Carless, D. (2006). Differing Perceptions in the Feedback Process. Studies in Higher Education,31(2).

Chandler, J. (2003). The Efficacy of Various Kinds of Feedback for Improvement in the Accuracy and Fluency of L2 Student Writing. Journal of Second Language Writing 12 (3), 267-296.

Dahar, M.A et al. (2009). Prior achievement is the indicator of use of school resources and the predictor of academic achievement in Punjab (Pakistan). Islamabad: Munich Personal RePEc Archive

Dulay, H, et al. (1982). Language Two. New York: Oxford University Press.

Ferris, D. R. (2003). Response to student writing: Implications for second language students.

Mahwah, NJ: Lawrence Erlbaum Associates, Inc.

Ellis, R. (1994). The Study of Second Language Acquisition. New York: Oxford University 
Press.

James, C. (2013). Errors in Language Learning and Use: Exploring Error Analysis. London: Longman.

Oshima, A and Ann Hogue. (2006). Writing Academic English. New York: Pearson Education.

Perkins, D. (1992). Smart school: Better thinking and learning for every child. New York: The Free Press.

Reigeluth, C.M. (2011). Instructional Theory and Technology for the New Paradigm of Education. Bloomington: Indiana University.

Saleh, M. (2012). Beginning Research in English Language Teaching. Semarang: Widya Karya

Sukestiyarno. (2011). Olah Data penelitian Bebantuan SPSS. Semarang: UNNES 